\title{
SUNKIA IR VIDUTINE ASTMA SERGANČIŲ VAIKŲ PATIRIAMAS NUOVARGIS
}

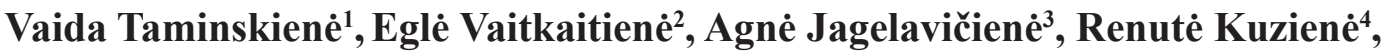 \\ Raimunda Jurgiliené $\dot{e}^{5}$, Danguolẻ Tamošiūnien $\dot{~}^{5}$, Larisa Jevsiukova ${ }^{6}$, Vilma Lukošienẻ ${ }^{7}$, \\ Salomėja Keršanskiene் ${ }^{8}$, Arūnas Valiulis ${ }^{1,3}$ \\ ${ }^{1}$ Vilniaus universiteto Medicinos fakulteto Sveikatos mokslu instituto Visuomenès sveikatos katedra, \\ ${ }^{2}$ Lietuvos sveikatos mokslu universiteto Medicinos akademija, ${ }^{3}$ Vilniaus universiteto Medicinos \\ fakulteto Klinikinès medicinos instituto Vaiku ligu klinika, ${ }^{4} V \check{S} I$ Šeškinès poliklinika, \\ ${ }^{5} V_{S} I$ Centro poliklinika, ${ }^{6}$ ŠL I Antakalnio poliklinika, \\ ${ }^{7} V_{s} I$ Kèdainiu ligonine, konsultaciju poliklinika, ${ }^{8}$ Vilniaus sveikatos namai
}

Raktažodžiai: bronchų astma, nuovargis, vaikai.

\begin{abstract}
Santrauka
Lètinès ligos - svarbus padidejusio vaikų nuovargio rizikos veiksnys. Kadangi astma yra viena labiausiai paplitusių lètinių vaikų ligų, ženkliai veikianti kasdieni paciento ir jo šeimos narių gyvenimą, šio tyrimo tikslas - įvertinti sunkia ir vidutine astma sergančiuc vaikų patiriamą nuovargị vaikų ir tėvų vertinimu bei jị sąlygojančius veiksnius.

I tyrimą itrauktas 151 sunkia ir vidutine astma sergantis 2-17 metų amžiaus vaikas ir jų tèvai. Pagrindinis tyrimo instrumentas - klausimynų komplektas, kurị pildè vaikai ir jų tèvai, atvykę planinio vizito pas vaikų pulmonologą. Vaikų patiriamo nuovargio vertinimui naudota PedsQL daugiamate nuovargio skalè, nuovargis vertintas 100 balų sistema, didesnis balas rodo mažesnį nuovargị. Siekiant nustatyti svarbiausius veiksnius, susijusius su didesniu vaikų patiriamu nuovargiu, atlikta logistinè regresija.

Sunkia ir vidutine astma sergančių vaikų suminis nuovargio balas buvo $66,4( \pm 16,3)$ vaikų ir $69,8( \pm 17,4)$ tèvų vertinimu. Svarbiausi sunkia ir vidutine astma sergančių vaikų didesnio nuovargio rizikos veiksniai buvo astmos simptomų buvimas ir dažnis, taip pat šeimos gaunama socialinè parama.
\end{abstract}

\section{Ivadas}

Bronchų astma - viena dažniausių lètinių neinfekcinių vaikų ligų. Jos paplitimas skirtingose šalyse skiriasi, tačiau tai aktuali visuomenès sveikatos problema visame pasaulyje, o jos našta ženkli ne tik pacientui ir jo šeimai, bet ir visai visuomenei. Astma sukelia ịvairius kvėpavimo sistemos simptomus: dusulị, švokštimą ir kitus, taip pat sutrikdo kasdienị vaiko ir jo šeimos gyvenimą, neigiamai veikia subjektyviai suvokiamą sveikatos būklę, gyvenimo kokybę, sukelia psichologinių problemų [1]. Astma sergantys vaikai turi riboti judrius žaidimus, kitas aktyvias veiklas, negali žaisti su gyvūnais ir bendraamžiais, dažnai jaučiasi kitokie dèl savo ligos ir jos gydymo, patiria neigiamas emocijas. Dèl astmos nukenčia vaikų miego kokybė, jie patiria sunkumų mokantis, apetito pokyčiu, taip pat dažniau jaučiasi pavargę [2]. Daugelis tyrimų rodo, kad daugiau sunkumų ir problemų patiria sunkia ir vidutine nei lengva astma sergantys vaikai [3].

Nuovargis - dažna lètinių ligų pasekmè sergančiam vaikui, tačiau jo profilaktikai ir valdymui dažnai nėra skiriama pakankamai dėmesio [4]. Bronchų astma nėra išimtis. Nors yra nemažai tyrimų, analizuojančių reumatinėmis ar onkologinèmis ligomis sergančių vaikų nuovargị, tačiau tyrimų, skirtu ịvertinti bronchų astma sergančių vaikų nuovargị nèra daug [5]. Tai viena esminių priežasčių, nulèmusių šio tyrimo tikslą.

Darbo tikslas - ivvertinti sunkia ir vidutine astma sergančių vaikų patiriamą nuovargị vaikų ir tėvų vertinimu bei jị sąlygojančius veiksnius.

\section{Tyrimo medžiaga ir metodai}

Atliktas momentinis paplitimo tyrimas. Tyrimo duomenys rinkti 2014-2016 metais Vilniaus ir Kauno apskrityse, šešiose asmens sveikatos priežiūros įstaigose, kuriose konsultuoja gydytojas vaiku pulmonologas. Dalyvauti tyrime buvo kviečiami tiriamieji, atvykę planinio vizito pas gydy- 
toją vaikų pulmonologą. Apklausti sunkia ir vidutine astma sergantys 2-17 metų amžiaus vaikai ir jų tèvai. Pagrindinis tyrimo instrumentas - klausimynų komplektas, kurị sudaro:

- Bendrasis klausimynas. Sudarytas tyrèjų, sudaro 4 dalys ir 36 klausimai. Skirtas įvertinti bendrąsias tiriamuju charakteristikas, socialinius, gyvensenos ir gyvenamosios aplinkos aspektus, ligos sunkumą, patiriamus simptomus, gaunamą gydymą. Klausimyną pildè tèvai.

- PedsQL daugiamatè nuovargio skalè. Sudaryta iš 3 skalių (bendras nuovargis, miegas/poilsis, pažinimo nuovargis) po 6 klausimus. Amžiui pritaikytas (2-4 m., 5-7 m., 8-12 m., 13-18 m.) atskiras klausimyno versijas pildè tèvai ir vaikai nuo penkerių metų amžiaus. Jaunesni vaikai buvo apklausiami interviu metodu, naudojant vaizdines priemones, vyresni klausimynus pilde savarankiškai. Nuovargis buvo vertinamas nuo 0 iki 100 balų. Didesnis balas rodo mažesni vaikų patiriamą nuovargi [6].

- Vaikų astmos kontrolès testas (VAKT) / Astmos kontrolès testas (AKT). Skirti ịvertinti astmos kontrolę. Vaikai nuo 4 iki 11 metų VAKT pildè kartu su tèvais, vyresni vaikai AKT pilde savarankiškai. VAKT vertinamas balais nuo 0 iki

1 lentelè. Bendrosios tiriamųjų charakteristikos.

\begin{tabular}{|c|c|c|c|}
\hline \multicolumn{2}{|c|}{ Charakteristikos } & \multirow{2}{*}{\begin{tabular}{|c|} 
Abs. sk. \\
117
\end{tabular}} & \multirow{2}{*}{$\frac{\text { Procentai }}{77,5}$} \\
\hline \multirow{3}{*}{$\begin{array}{l}\text { Astmos } \\
\text { forma }\end{array}$} & Alerginè & & \\
\hline & Mišri & 20 & 13,2 \\
\hline & Nealerginè & 14 & 9,3 \\
\hline \multirow{3}{*}{$\begin{array}{l}\text { Astmos } \\
\text { kontrolè }\end{array}$} & Kontroliuojama & 70 & 48,3 \\
\hline & Iš dalies kontroliuojama & 48 & 33,1 \\
\hline & Nekontroliuojama & 27 & 18,6 \\
\hline \multirow{4}{*}{$\begin{array}{l}\text { Šeimos } \\
\text { darna }\end{array}$} & Vaikas auga su abiem tèvais & 114 & 75,5 \\
\hline & Vaikas auga su vienu iš tėvų & 16 & 10,6 \\
\hline & Tėvai išsiskyrę & 20 & 13,2 \\
\hline & $\begin{array}{c}\text { Vaikas auga su seneliais/ } \\
\text { giminaičiais }\end{array}$ & 1 & 0,7 \\
\hline \multirow{2}{*}{$\begin{array}{l}\text { Pragy- } \\
\text { venimo } \\
\text { Šaltinis }\end{array}$} & Nuolatinis darbas & 139 & 92,1 \\
\hline & Pašalpos & 30 & 19,9 \\
\hline \multirow{6}{*}{$\begin{array}{l}\text { Mamos/ } \\
\text { tečcio išsila- } \\
\text { vinimas }\end{array}$} & Pradinis & $1 / 2$ & $0,7 / 1,5$ \\
\hline & Pagrindinis & $3 / 4$ & $2,0 / 2,9$ \\
\hline & Vidurinis, spec. vidurinis & $26 / 40$ & $17,3 / 29,4$ \\
\hline & Aukštesnysis & $29 / 24$ & $19,3 / 17,6$ \\
\hline & Nebaigtas aukštasis & $5 / 5$ & $3,3 / 3,7$ \\
\hline & Aukštasis & $86 / 61$ & $57,3 / 44,9$ \\
\hline \multirow{6}{*}{$\begin{array}{l}\text { Pajamos } \\
\text { vienam } \\
\text { šeimos } \\
\text { nariui }\end{array}$} & Iki 150 Eur/mėn. & 20 & 13,2 \\
\hline & 151-300 Eur/mėn. & 36 & 23,8 \\
\hline & 301-450 Eur/mėn. & 27 & 17,9 \\
\hline & 451-600 Eur/mèn. & 16 & 10,6 \\
\hline & >600 Eur/mėn. & 16 & 0,6 \\
\hline & Nenorèčiau nurodyti & 36 & 23,8 \\
\hline
\end{tabular}

27, AKT nuo 5 iki 25. Didesnis balas rodo geresnę astmos kontrolę: $\geq 20$ kontroliuojama astma, 19-16 - iš dalies kontroliuojama, o $\leq 15$ - nekontroliuojama [7].

Statistinei duomenų analizei naudotas statistinis paketas SPSS, versija 22.0, Microsoft Office Excel 2013. Taikyta aprašomoji statistika. Kategoriniai duomenys aprašyti absoliučiais skaičiais ir procentais, tolydūs - vidurkiu ir standartiniu nuokrypiu $( \pm \mathrm{SN})$ arba mediana ir kvartilèmis. Duomenų analizei naudota Spirmeno (Spearman) koreliacija, Stjudento (Student) $\mathrm{t}$ testas, dispersinè analizè (ANOVA). Siekiant suprasti svarbiausius sunkia ir vidutine astma sergančių vaikų patiriamo nuovargio rizikos veiksnius, atlikta dvinarè logistinė regresija. PedsQL daugiamatès nuovargio skalès balai buvo suskirstyti į tris lygias dalis - terciles. Pirma tercilè (PedsQL daugiamatès nuovargio skalès balai $\leq 33$-ia procentilè, arba $\leq 62,5$ balo vaikų vertinimu ir $\leq 63,9$ balo tèvų vertinimu) buvo apibrèžta kaip didesnis nuovargis ir lyginama su aukštesniais balais. Sudarant regresijos modelius buvo įtraukiami statistiškai reikšmingai su priklausomu kintamuoju (vaikų patiriamu nuovargiu) susiję, taip pat epidemiologiškai svarbūs kintamieji. Rezultatai buvo vertinami kaip statistiškai reikšmingi, kai $\mathrm{p} \leq 0,05$.

Tyrimui atlikti gautas Vilniaus regioninio Biomedicininių tyrimų Etikos komiteto leidimas.

\section{Rezultatai}

Tyrime dalyvavo 151 sunkia ir vidutine astma sergantis 2-17 metų amžiaus vaikas ir jų tèvai. Tiriamųjų amžiaus vidurkis $9,3( \pm 40,9) \mathrm{m} ., 70,2$ proc. berniukai. 10,6 proc. apklaustų vaikų buvo diagnozuota sunki, 89,4 proc. - vidutiné bronchų astma. Kitos bendrosios respondentų charakteristikos pateikiamos 1-oje lentelèje.

Sunkia ir vidutine astma sergančių vaikų suminis nuovargio balas tiek vaikų, tiek tèvų vertinimu viršijo 65 iš 100 galimų. Vaikų vertinimu jų patiriamas nuovargis buvo didesnis

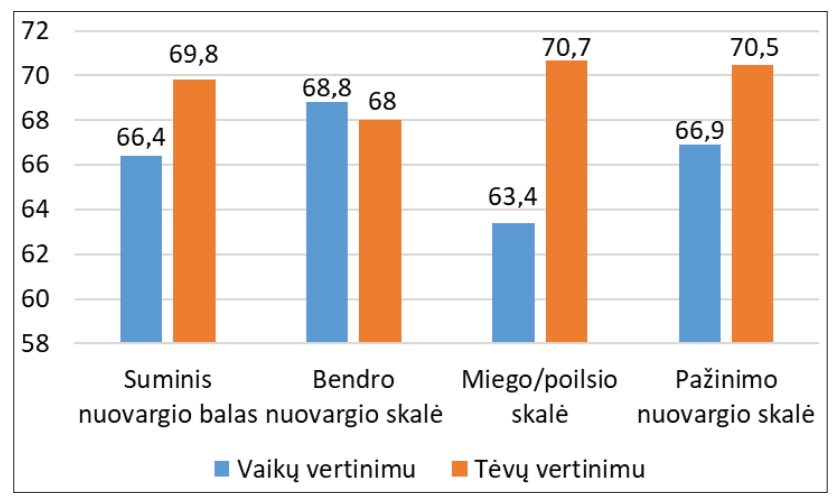

1 paveikslas. Nuovargio balai vaikų ir tèvų vertinimu. 
2 lentelè. Nuovargio sąsajos su aplinkos, socialiniais ir gyvensenos veiksniais.

${ }^{*} p<0,05 ; * *_{p}<0,001$

\begin{tabular}{|c|c|c|c|}
\hline \multicolumn{2}{|l|}{ Veiksniai } & $\begin{array}{c}\text { Suminis } \\
\text { nuovargio } \\
\text { balas vaiku } \\
\text { vertinimu, vi- } \\
\text { durkis }( \pm \mathrm{SN})\end{array}$ & $\begin{array}{c}\text { Suminis nuo- } \\
\text { vargio balas } \\
\text { tėvų vertinimo, } \\
\text { vidurkis }( \pm \mathrm{SN})\end{array}$ \\
\hline \multirow[t]{2}{*}{ Astmos sunkumas } & Sunki & $55,9( \pm 20,4)^{*}$ & $57,9( \pm 15,4)^{*}$ \\
\hline & Vidutine & $67,8( \pm 15,2)$ & $71,2( \pm 17,1)$ \\
\hline \multirow{3}{*}{ Astmos forma } & Alerginė & $66,5( \pm 15,9)$ & $69,4( \pm 16,5)$ \\
\hline & Nealerginè & $65,7( \pm 13,8)$ & $70,2( \pm 21,4)$ \\
\hline & Mišri & $66,0( \pm 20,9)$ & $71,8( \pm 20,3)$ \\
\hline \multirow{4}{*}{ Sezonas } & Pavasaris & $62,9( \pm 14,7)$ & $66,9( \pm 18,9)$ \\
\hline & Vasara & $64,1( \pm 20,7)$ & $64,9( \pm 20,4)$ \\
\hline & Ruduo & $69,0( \pm 15,9)$ & $73,4( \pm 16,9)$ \\
\hline & Žiema & $69,9( \pm 15,1)$ & $72,5( \pm 14,8)$ \\
\hline \multirow{2}{*}{$\begin{array}{l}\text { Pašalpos, kaip } \\
\text { pagrindinis pajamų } \\
\text { šaltinis }\end{array}$} & Taip & $59,6( \pm 16,3)^{*}$ & $57,4( \pm 20,1)^{* *}$ \\
\hline & $\mathrm{Ne}$ & $68,3( \pm 15,8)$ & $72,8( \pm 15,3)$ \\
\hline \multirow[t]{2}{*}{ Lanko būrelius } & Taip & $67,6( \pm 16,0)$ & $71,8( \pm 16,7)^{*}$ \\
\hline & $\mathrm{Ne}$ & $63,4( \pm 16,6)$ & $64,9( \pm 18,3)$ \\
\hline \multirow[t]{2}{*}{ Lydinčios alergijos } & Taip & $66,9( \pm 17,2)$ & $68,8( \pm 17,3)$ \\
\hline & $\mathrm{Ne}$ & $64,9( \pm 13,5)$ & $71,9( \pm 17,6)$ \\
\hline \multirow{2}{*}{$\begin{array}{l}\text { Dèl vaiko astmos } \\
\text { šeima patyrė dides- } \\
\text { nių sunkumų }\end{array}$} & Taip & $65,1( \pm 15,2)$ & $66,2( \pm 16,7)^{*}$ \\
\hline & $\mathrm{Ne}$ & $67,8( \pm 17,4)$ & $73,6( \pm 17,5)$ \\
\hline \multirow{2}{*}{$\begin{array}{l}\text { Dusulys per paskuti- } \\
\text { nius metus }\end{array}$} & Taip & $64,2( \pm 15,6)^{*}$ & $66,6( \pm 16,9)^{* *}$ \\
\hline & $\mathrm{Ne}$ & $76,4( \pm 14,9)$ & $82,2( \pm 13,1)$ \\
\hline \multirow{2}{*}{$\begin{array}{l}\text { Astmos simptomai } \\
\text { beveik kiekvieną } \\
\text { naktị }\end{array}$} & Taip & $58,12( \pm 19,8)$ & $60,4( \pm 16,9)^{*}$ \\
\hline & $\mathrm{Ne}$ & $67,28( \pm 15,7)$ & $70,7( \pm 17,2)$ \\
\hline
\end{tabular}

nei tėvu vertinimu, tačiau šis skirtumas nebuvo statistiškai reikšmingas $(\mathrm{p}=0,264)$. Vaikai prasčiausiai vertino miego ir poilsio skalę, geriausiai bendro nuovargio, tèvai - atvirkščiai (1 pav.).

Analizuojant sunkia ir vidutine astma sergančių vaikų patiriamą nuovargi, buvo vertinamos nuovargio sąsajos su aplinkos, socialiniais, gyvensenos ir kitais galimais rizikos veiksniais.

Berniukų ir mergaičių patiriamas nuovargis buvo panašus. Vyresni vaikai jautė didesnį nuovargi nei jaunesni, tačiau tik tėvų vertinimu (rho $=-0,207 ; p=0,011)$. Tik tèvų vertinimu didesnis nuovargis buvo susijęs su didesniu vaiko kūno masès indeksu ( $r$ ro $=-0,206 ; p=0,016$ ) ir mažesnèmis šeimos pajamomis ( $r h o=0,247 ; p=0,008)$. Didesnis vaiko nuovargis buvo susijęs su dažnesniais astmos simptomais nakties metu (vaikų vertinimu rho $=-0,181 ; p=0,041$; tèvu vertinimu rho $=-0,219 ; \mathrm{p}=0,008)$, blogesne bendra vaiko sveikatos būkle (vaikų vertinimu rho $=0,216 ; \mathrm{p}=0,013$; tèvų vertinimu rho $=0,329 ; \mathrm{p}<0,001)$, prastesne astmos kontrole (vaikų vertinimu rho $=0,203 ; p=0,020$; tèvų vertinimu rho $=0,248 ; \mathrm{p}=0,003)$.
3 lentelè. Sunkia ir vidutine astma sergančių vaikų patiriamo nuovargio sąsajos su galimais rizikos veiksniais vaikų ir tẻvų vertinimu. ${ }^{I} N=125 ;$ Wald-chi ${ }^{2}=7,526 ; p=0,006 ;$ Hosmer-Lemešou testo ch $^{2}{ }^{2}=0,391 ; d f=3 ;$ $p=0,942$; teisingai suklasifikuota $62,4 \%$; Nagelkerkès $R^{2}=0,159$

${ }^{2} N=144 ;$ Wald-chi ${ }^{2}=10,815 ; p=0,001 ;$ Hosmer-Lemešou testo chi $^{2}=0,399 ; d f=3$; $p=0,940$; teisingai suklasifikuota $63,9 \%$; Nagelkerkès $R^{2}=0,303$

\begin{tabular}{|c|c|c|c|c|c|c|}
\hline \multirow[b]{2}{*}{$\begin{array}{l}\text { Veiks- } \\
\text { niai }\end{array}$} & \multicolumn{3}{|c|}{ Nuovargis vaikų vertinimu ${ }^{1}$} & \multicolumn{3}{|c|}{ Nuovargis tèvų vertinimu ${ }^{2}$} \\
\hline & $\check{S}_{\mathrm{S}}$ & $\breve{S S}_{\mathrm{p}}(95 \% \mathrm{PI})$ & p & $\check{\mathbf{S S}}_{\mathbf{b}}$ & $\check{S S}_{\mathrm{p}}(95 \% \mathrm{PI})$ & p \\
\hline \multicolumn{7}{|c|}{ Pašalpos kaip pragyvenimo šaltinis } \\
\hline Taip & 2,46 & $2,48(1,01-6,10)$ & 0,048 & 5,12 & $7,49(2,74-20,47)$ & $<0,001$ \\
\hline $\mathrm{Ne}$ & 1 & 1 & & 1 & 1 & \\
\hline \multicolumn{7}{|c|}{ Dusulys per paskutinius metus } \\
\hline Taip & 5,06 & $5,03(1,38-18,44)$ & 0,015 & 7,52 & $8,13(2,17-30,41)$ & 0,002 \\
\hline $\mathrm{Ne}$ & 1 & 1 & & 1 & 1 & \\
\hline \multicolumn{7}{|c|}{ Astmos simptomai beveik kiekvieną naktị } \\
\hline Taip & 2,89 & $3,44(0,97-12,14)$ & 0,055 & 2,64 & $3,72(1,03-13,39)$ & 0,045 \\
\hline $\mathrm{Ne}$ & 1 & 1 & & 1 & 1 & \\
\hline
\end{tabular}

Kaip matyti iš 2-osios lentelès, mažesnị nuovargị juto vaikai, sergantys vidutine astma, palyginus su sunkia, taip pat vaikai, kurie per paskutinius metus nejuto dusulio, tačiau patiriamas nuovargis nebuvo susijęs su astmos forma, metų laiku, lydinčiomis alerginèmis ligomis, astmos rizikos veiksniais namuose: pasyviu rūkymu, židinio ar pelessio buvimu, naminiais gyvūnèliais.

Vaikai, kurie dažniau patirdavo astmos simptomus naktį, taip pat vaikai iš šeimų, kurių vienas pagrindinių pajamų šaltinių buvo pašalpos, bei kurių šeimos patyre didesnių sunkumų dèl vaiko ligos jautèsi labiau pavargę. Mažesnị nuovargị patiriantys vaikai dažniau lankè įvairius būrelius.

Siekiant nustatyti svarbiausius sunkia ir vidutine astma sergančiu vaikų patiriamo nuovargio rizikos veiksnius, buvo atlikta dvinarè logistinè regresija (3 lentelè). Reikšmingiausiai su didesniu nuovargiu buvo susijęs dusulys per paskutinius metus ir socialinè šeimos gaunama parama. Tẻvų vertinimu, vaikų nuovargio riziką daugiau nei 3 kartus didino astmos simptomai, patiriami beveik kiekvieną nakti. İdomu tai, kad nei vaikų, nei tėvų vertinimu astmos sunkumas ir kontrolè nebuvo statistiškai reikšmingai susiję su nuovargio lygiu.

\section{Rezultatų aptarimas}

Kasdieniame gyvenime nuovargi patiria daugelis vaiku, tačiau ši problema dar aktualesnè tarp sveikatos sutrikimų turinčių vaikų. Bronchų astma, kaip lètinė liga, apsunkina sergančių vaikų kasdienį funkcionavimą ne tik dèl fizinių simptomų, vaistų vartojimo, psichologinių sunkumų, bet ir padidejjusio nuovargio [2]. Tyrimo rezultatai parode, kad sunkia ir vidutine astma sergantys vaikai patiria didesnį nuovargị nei sveiki vaikai [8] ar bendraamžiai, sergantys lengvesne ligos eiga [5]. Taip pat nustatyta, kad tèvai nepakankamai ịver- 
tina astma sergančių vaikų nuovargị - suminiai PedsQL daugiamatès nuovargio skalès balai buvo didesni tèvų nei vaikų vertinimu. Tai atspindi ir prieš tai atliktų tyrimų rezultatus, kur tiek sveikų, tiek lètinėmis ligomis sergančių vaikų nuovargio balai buvo mažesni vaikų nei jų tėvų vertinimu $[2,8,9]$.

Analizuojant sunkia ir vidutine astma sergančių vaikų nuovargio sąsajas su galimais rizikos veiksniais, nustatyta, kad berniukų ir mergaičių patiriamas nuovargis buvo panašus, priešingai nei olandų, kurių berniukai jautèsi labiau pavargę nei mergaitès [10]. Kita vertus, abiejuose tyrimuose labiau pavargę jautėsi vyresni nei jaunesni vaikai. Tai galèjo nulemti paprastai trumpesnè vyresnių vaikų miego trukmé ir didesni krūviai ugdymo įstaigose [5].

Gerai žinoma, kad astmos eigai ir sergančiujų gyvenimo kokybei didelę neigiamą įtaką daro rizikos veiksniai: lydinčios alerginès ligos [11], pasyvus rūkymas namuose [12], tačiau šiame tyrime sąsajų tarp astmos rizikos veiksnių ir nuovargio aptikti nepavyko. Vaikų patiriamas nuovargis taip pat nebuvo susijęs su astmos forma ar metų laiku. İdomu tai, kad bronchų astmos sunkumas ir kontrolè, žinomi kaip pagrindiniai paciento gyvenimo kokybę lemiantys veiksniai $[13,14]$, buvo susiję su vaiko patiriamu nuovargiu, tačiau tik pirminèje analizeje ir ị galutinius logistinès regresijos modelius nepateko.

Svarbiausi rizikos veiksniai, susiję su didesniu vaiko patiriamu nuovargiu, buvo astmos simptomai ir jų dažnis, taip pat šeimos gaunama socialinè parama, tačiau tik tẻvu vertinimu. Astmos simptomai, ypač nakties metu, sutrikdo miego trukmę ir kokybę, o tai yra vienas didžiausių padidèjusio nuovargio rizikos veiksnių [15]. Nustatytos didesnio vaikų nuovargio sąsajos su žemesne socialine ekonomine šeimos padètimi taip pat patvirtina ankstesnių tyrimų rezultatus $[10,14]$.

Atliktas tyrimas turi privalumų ir trūkumų. Nuovargiui vertinti naudota tarptautinio klausimyno PedsQL daugiamatès nuovargio skalès lietuviška versija, kuri leidžia visapusiškai įvertinti nuovargị: klausimyną sudaro 3 skalès, skirtos ivertinti skirtingus nuovargio aspektus (bendrą nuovargi, miegą/poilsị, pažinimo nuovargi) ), klausimynai pritaikyti skirtingoms amžiaus grupėms, taip pat atskirai vaikų nuovargi vertina patys vaikai ir jų tevvai. Tyrimo rezultatus galima lyginti su kitais tyrimais, kuriuose naudotas tas pats instrumentas. Klausimynas nèra specifinis, taigi rezultatus galima lyginti tiek su kontroline sveikų vaikų grupe, tiek su kitomis ligomis sergančių vaikų patiriamu nuovargiu. Nors tai nebuvo daryta šiame tyrime, galètų būti ateities tyrimų objektas. Tyrimo rezultatai taip pat būtų išsamesni, jei būtų surinkta didesnè sunkia astma sergančių vaikų imtis, o duomenys būtų rinkti ne tik Vilniaus ir Kauno apskrityse, bet visoje Lietuvoje.

\section{Išvados}

1. Bronchų astma - reikšmingas vaikų nuovargio rizikos veiksnys. Sunkia ir vidutine astma sergančių vaikų nuovargis yra didesnis nei sergančių lengva ligos eiga bei prilygsta kitomis lètinèmis ligomis sergančių vaikų nuovargiui.

2. Astmos simptomų buvimas ir dažnis daro didžiausią itaką vaikų patiriamam nuovargiui. Žemesnè socialinè ekonominè padėtis taip pat didina didesnio nuovargio riziką.

\section{Literatūra}

1. Asher I, Pearce N. Global burden of asthma among children. Int J Tuberc Lung Dis 2014; 18(11):1269-1278.

https://doi.org/10.5588/ijtld.14.0170

2. Taminskienè V., Vaitkaitienè E., Valiulis A. Bronchų astmos ir gyvenimo kokybės tarpusavio sąveika vaikysteje ir paauglystèje. Vaikų pulmonologija ir alergologija, 2013; 16(2):80-85.

3. Stucky BD, Sherbourne CD, Orlando Edelen M, Eberhart NK. Understanding asthma-specific quality of life: moving beyond asthma symptoms and severity. Eur Respir J 2015; 46(3):680687.

https://doi.org/10.1183/09031936.00225014

4. Steenbruggen TG, Hoekstra SJ, van der Gaag EJ. Could a change in diet revitalize children who suffer from unresolved fatigue? Nutrients 2015; 7(3):1965-1977.

https://doi.org/10.3390/nu7031965

5. Taminskienė V., Vaitkaitienè E., Lukošienė V., Keršanskienė S., Valiulis A. Bronchų astma ir jos įtaka nuovargiui: preliminarūs prospektyvaus tyrimo duomenys. Vaikų pulmonologija ir alergologija, 2015; 18(2):15-21.

6. Crichton A, Knight S, Oakley E, Babl FE, Anderson V. Fatigue in child chronic health conditions: a systematic review of assessment instruments. Pediatrics 2015; 135(4): e1015-e1031. https://doi.org/10.1542/peds.2014-2440

7. Cloutier MM, Schatz M, Castro M, Clark N, Kelly HW, Mangione-Smith R, et al. Asthma outcomes: composite scores of asthma control. J Allergy Clin Immunol 2012; 129(3): S24-33. https://doi.org/10.1016/j.jaci.2011.12.980

8. Panepinto JA, Torres S, Bendo CB, McCavit TL, Dinu B, Sherman-Bien S, Bemrich-Stolz C, Varni JW. PedsQL TM Multidimensional Fatigue Scale in sickle cell disease: feasibility, reliability, and validity. Pediatr Blood Cancer 2014; 61(1):171177.

https://doi.org/10.1002/pbc.24776

9. Ye Q, Liu K, Wang J, Bu X, Zhao L. Reliability and validity of the Chinese version of the PedsQL Multidimensional Fatigue Scale in children with acute leukemia. International Journal of Nursing Sciences 2016; 3(2):146-152.

https://doi.org/10.1016/j.ijnss.2016.04.001

10. Gordijn MS, Cremers EMP, Kaspers GJL, Gemke RJBJ. Fatigue in children: reliability and validity of the Dutch PedsQLTM Multidimensional Fatigue Scale. Qual Life Res 2011; 
20:1103-1108.

https://doi.org/10.1007/s11136-010-9836-9

11. Haanpää L, af Ursin P, Nermes M, Kaljonen A, Isolauri E. Association of allergic diseases with children's life satisfaction: population based study in Finland. BMJ open 2018; 8(3): e019281. doi: 10.1136/bmjopen-2017-019281

https://doi.org/10.1136/bmjopen-2017-019281

12. Kalyva E, Eiser C, Papathanasiou A. Health-related quality of life of children with asthma: self and parental perceptions. Int J Behav Med 2016; 23(6): 730-737. https://doi.org/10.1007/s12529-016-9558-7

13. Petsios KT, Priftis KN, Hatziagorou E, Tsanakas JN, Antonogeorgos G, Matziou VN. Determinants of quality of life in children with asthma. Pediatr Pulmonol 2013; 48(12); 1171-1180.

https://doi.org/10.1002/ppul.22768

14. Turner SW, Mehta A, Ayres JG, Palmer CN, Mukhopadhyay S. G153 determinants of quality of life in children with asthma who live in Scotland. Arch Dis Child 2013; 98(Suppl 1): A71A71.

https://doi.org/10.1136/archdischild-2013-304107.165

15. Tham SW, Holley AL, Zhou C, Clarke GN, Palermo TM. Longitudinal course and risk factors for fatigue in adolescents: the mediating role of sleep disturbances. J Pediatr Psychol 2013; 38(10): 1070-1080.

https://doi.org/10.1093/jpepsy/jst051
FATIGUE IN CHILDREN WITH MODERATE AND

SEVERE ASTHMA

V.Taminskienė, E.Vaitkaitienė, A.Jagelavičienė, R.Kuzienė, R.Jurgilienè, D.Tamošiūnienė, L.Jevsiukova, V.Lukošienė, S.Keršanskienè, A.Valiulis.

Key words: asthma, children, fatigue.

Summary

Chronic diseases are important risk factor of increased level of children fatigue. Since asthma is one of the most prevalent chronic diseases among children and has significant impact on everyday life of patient and family members, the aim of our study was to evaluate fatigue in children with moderate and severe asthma by self and proxy reports and factors associated with it.

We enrolled 151 child with moderate and severe asthma and their parents into the study. The main instrument of the study - a set of questionnaires completed by both children and their parents who came for a planned visit to a paediatric pulmonologist. Children fatigue was assessed by PedsQL Multidimensional Fatigue Scale using 100-point system where higher scores correspond to lower level of fatigue. In order to understand the most important factors associated with higher levels of fatigue, binary logistic regression was performed.

The total scores of fatigue in children with moderate and severe asthma were $66.4( \pm 16.3)$ by children self and $69.8( \pm 17.4)$ by parent proxy reports. The most important risk factors of higher level of fatigue were presence and frequency of asthma symptoms as well as social support received by the family.

Correspondence to: vaida.taminskiene@mf.vu.lt 